\title{
The Processing of Felonies in the Superior Court of Alameda County 1880-1974
}

\author{
Lawrence M. Friedman and Robert V. Percival
}

\section{Introduction}

It hardly needs to be said that public opinion is much agitated by the problem of crime. Polls show that people rank crime as one of the most serious issues facing society. ${ }^{1}$ A constantly growing amount of effort and research has gone into the question of what to do about crime. It is only natural that the interest in crime should spill over into many disciplines, including history, though, until recently, very few studies focussed on this chapter of social history and only a handful of these were quantitative. The number of such studies is now starting to grow. ${ }^{2}$

Lawrence M. Friedman is Marion Rice Kirkwood Professor of Law, Stanford University.

Robert V. Percival is Assistant Professor of Law, University of Maryland Law School.

The work done on this report was carried out under LEAA Grant No. 75-N1-99-0086, Stanford Law School, and NSF Grant No. SOC 76-24217. The authors wish to thank Clifford J. Halverson for his great assistance with the research. Jonathan Casper made valuable comments on an earlier draft. We also wish to thank the Clerk of the Court of Alameda County Superior Court and his staff for their cooperation, and to acknowledge the assistance of the following while students at Stanford Law School: Arlene Bobrow, Thomas Devine, Jack Gillman, Walter Lion, Carol Lombardini, Craig Nelson, and Lawrence Ponoroff.

1. 'Crime was the biggest concern for Americans. Lawlessness in general, drug abuse, and criminal acts by public officials were all in the top five issues.' New York Times, June 4, 1976, 12 (reporting an Associated Press poll). See also John E. Conklin, The Impact of Crime (New York, 1975) 76-77.

A survey in 1975 asked a sample of the population whether the government was spending too much, enough, or too little on 'halting the rising crime rate'. Of those who responded 974 said 'too little', 345 'about right', and only 81 'too much'. National Data Program for the Social Sciences Spring 1975 General Social Survey (Ann Arbor, 1975) 98.

2. See for example, Eric H. Monkkonen, The Dangerous Class, Crime and Poverty in Columbus, Ohio, 1860-1885 (Cambridge, Mass., 1975); Michael S. Hindus, Prison and Plantation: Crime, Justice and Authority in Massachusetts and South Carolina, 1767-1878 (Chapel Hill, 1980); Douglas Greenberg, Crime and Law Enforcement in the Colony of New York, 1691-1776 (Ithaca, 1976); Edward L. Ayers, Vengeance and Justice: Crime and Punishment in the 19th Century American South (New York, 1984). Ted Robert Gurr, Rogues, Rebels and Reformers, A Political History of Urban Crime and Conflict (Beverly Hills, 1976) looks at cross-national data. See also James Q. Wilson and Richard J. Herrnstein, Crime and Human Nature (New York, 1985) 439-58. 
This paper presents some data on felony prosecutions tried in the Superior Court of Alameda County, California between 1880 and $1974 .{ }^{3}$ The data are preliminary, and they raise almost as many questions as they answer. But they may provide a useful basis for considering how the criminal justice system has changed over time. Alameda County is a large urban county, situated on the east side of San Francisco Bay. In the 1970s, somewhat more than one million people lived in the county. The Superior Court has original jurisdiction over all felony cases in Alameda County. It also hears a small number of appeals from lower courts-justice courts and police courts. ${ }^{4}$ These appeals are heard de novo in the Superior Court, that is, they are completely retried, facts and all. 5 The Superior Court also entertains habeas corpus actions. (These actions have been excluded from this study.) The present court structure has remained more or less stable since 1880 , which simplifies the task of making comparisons over time.

This study is of those felony cases which were not filtered out before reaching Superior Court. Many-indeed most-felony charges fall by the wayside long before trial and conviction. In Chicago, in 1972, the police made 35,000 felony arrests; the court convicted 2,500 of these. ${ }^{6}$ Most of these were dismissed by magistrates. Chicago is an extreme case; but it is common everywhere for large numbers of felony cases to abort, or to be reduced to misdemeanors. This is a study of the survivors.

In its first years, the Superior Court did not carry a heavy load of criminal cases. The figures fluctuate oddly, for reasons that are not very clear. In 1921 , for example, there were 413 cases; in 1918, 179; in 1920, 272. In the 1880 s however, the court averaged about seventy felony cases per year. Shortly after 1910 , the court was averaging somewhat more than 200 cases a year; in the 1930 s the average was over 400 ; in 1950, 647 cases were filed;

3. California Penal Code $\$ 17$ defines felonies as crimes punishable by death or by imprisonment in the state prison. 'Every other crime', the section goes on to say, 'is a misdemeanor'.

4. For additional legal background on the county, see Lawrence M. Friedman and Robert V. Percival, 'A Tale of Two Courts: Litigation in Alameda and San Benito Counties', 10 Law \& Society Review 267 (1976) (reporting on a study of civil litigation). The criminal justice system of the county from 1870 to 1910 is treated in greater detail in Lawrence M. Friedman and Robert V. Percival, The Roots of Justice: Crime and Punishment in Alameda County, California, 1870-1910 (Chapel Hill, 1981) [hereinafter cited as Roots of Justice].

5. Some of these are cases of petty crimes or violations of ordinances, for example Maria Rogers, Crim. No. 53 (1880), convicted of allowing two cows to 'run at large upon a public street' of the town of Alameda, contrary to ordinance. Others seem to be cases pursued out of spite. Another example, Mary McGladry, Crim. No. 257, 1881, brought to justice in Glen Township Justice Court, was charged with beating her stepson 'about the head and face with a butcher knife'. A jury found her guilty, and sentenced her either to pay $\$ 30$, or work off her fine at $\$ 1$ a day in the County Jail. From this case, Mrs. McGladry appealed-and lost again.

6. James Eisenstein and Herbert Jacob, Felony Justice (Boston, 1977) 190. 
in 1960, 1063; in 1970, 2572. This was, however, an unusually high number of cases. In the last years covered by the study, the totals have somewhat declined. There were 2,001 felony cases filed in 1974. Between 1880 , when the court was organized, and the end of 1974 , about 53,000 felony cases were filed.

Obviously, we could not examine all these cases; it was necessary to sample. For the period 1880-1929, the total number of cases was 8,406; we drew a sample of twenty-five percent for 1880-1910, and a sample of five percent for 1910-1929. For the period from 1930 to 1974, there was something on the order of 44,000 cases. The sample drawn was one percent. Together, these gave us a total of roughly 1,500 cases. The actual number, after discarding habeas corpus and other miscellaneous files, was 1,487. Information about each case was drawn from Registers of criminal actions. These were sometimes incomplete; and we often looked at the case files themselves. We also read many other case files, at random, to gain more of a sense of what went on in court. These faded pieces of paper are, of course, only a pale reflection of reality. But they are as close as we can come to the vanished past. ${ }^{7}$

Through the period of the study, cases could reach Superior Court either through information or indictment. In some states, indictment by grand jury is the only legal way to set a felony prosecution in motion. This was the case in California before 1880. When a person was arrested, he was brought before a magistrate (a police judge or justice of the peace). If the magistrate felt there was probable cause, he sent the case to the grand jury to consider. The grand jury indicted or not, as it saw fit.

But this was a cumbersome system. The grand jury met only four times a year. Cases were first delayed for as much as three months, then considered in bunches. In 1880, California changed its law to allow prosecution through information. If the magistrate found probable cause, after a preliminary examination, he could bind the defendant over to Superior Court. Then the prosecution filed an information. The Superior Court was in continuous session and hence could avoid the delays of the grand jury. The grand jury was not abolished, but the information method was distinctly preferred in the county. In no year did indictment account for more than fifteen percent of all felony cases, and this was at the very beginning of the new system. For the period 1880-1909, as a whole, seven percent of the cases began by indictment; for the period 1950-1974, only one percent. (See Table 1.)

The grand jury, of course, had other functions. It was a general investigatory body, it looked into scandals and misconduct in office and it could recommend reforms in the system of justice. One grand jury, which

7. Registers and files are public records open (in theory) to anyone who wishes to look at them. But they record all sorts of vice and misery, and in practice only lawyers and a few stray scholars ever look at them. To avoid embarrassment to people who might still be alive, or to their families, we do not use full names for defendants in files opened after 1910. 
filed its final report in December, 1882, castigated Oakland for allowing pools of stagnant water near schools, analyzed the way the sheriff ran his office, complained about disgraceful conditions among insane people housed in the County Jail ('the English language does not contain the words sufficiently strong to express our abhorrence of this . . criminal neglect ...'), and recommended that a law be passed to set up a 'state school of industry' for young offenders. ${ }^{8}$ Grand jury indictment is used once in a while in cases where the grand jury's subpoena power may be needed (to develop evidence in secret, for example). It is used, too, for some cases that become embroiled in controversy. For example, if a police officer is accused of misconduct, the district attorney might ask for an indictment. If the grand jury does not indict, then it is not the district attorney's 'fault' that the case fell through, even if, in fact, he worked quietly to get the grand jury to ignore the case.

From 1935 on (Cal. Penal Code, §854a) a defendant could be brought before the Superior Court for sentencing by means of a so-called Certificate of Magistrate. The defendant is arraigned before the magistrate and pleads guilty there to the felony charge. The magistrate certifies the guilty plea to the Superior Court. This eliminates the need for a trial, and for any proceedings in Superior Court except sentencing. It is a quick and efficient way to process defendants. (It was authorized only if defendant was represented by counsel, and only if the crime was not capital.) Nearly half of the cases in Superior Court in the 1940s came up on these Certificates. More recently, the popularity of the Certificate has waned. Most defendants plead not guilty, and later plea-bargain. This has reduced the use of Certificates; in the 1970s less than fifteen percent of the cases come from magistrates in this way.

\section{Organization of the Court}

When the judicial system was reorganized in 1880 , the Superior Court of Alameda County came into existence. The Court was divided into two 'departments'. One department took over the work of the old District Court; it heard insolvency actions, and, in general, civil cases where the amount in controversy was over $\$ 300$. Its criminal work was confined to treason, murder and manslaughter cases. The second department handled, essentially, all the business of the old County Court, which included all the rest of the criminal cases, together with any appeals from misdemeanor

8. There was, it seemed, some question whether the Grand Jury was a worthwhile institution. A Grand Jury report filed March 24, 1897 complained that it was 'common practice to speak slightingly of Grand Juries and their usefulness and their work . . . [I]n our opinion the money invested in Grand Juries by our county is well spent. The fact that a Grand Jury is in existence is to a certain extent a restraint upon crime, and it is public notice to all citizens who have grievances that they can come before such juries with their complaints at any time and that they will be investigated.' 
TABLE 1

METHOD OF FILING CHARGES, ALAMEDA COUNTY SUPERIOR COURT 1880-1974

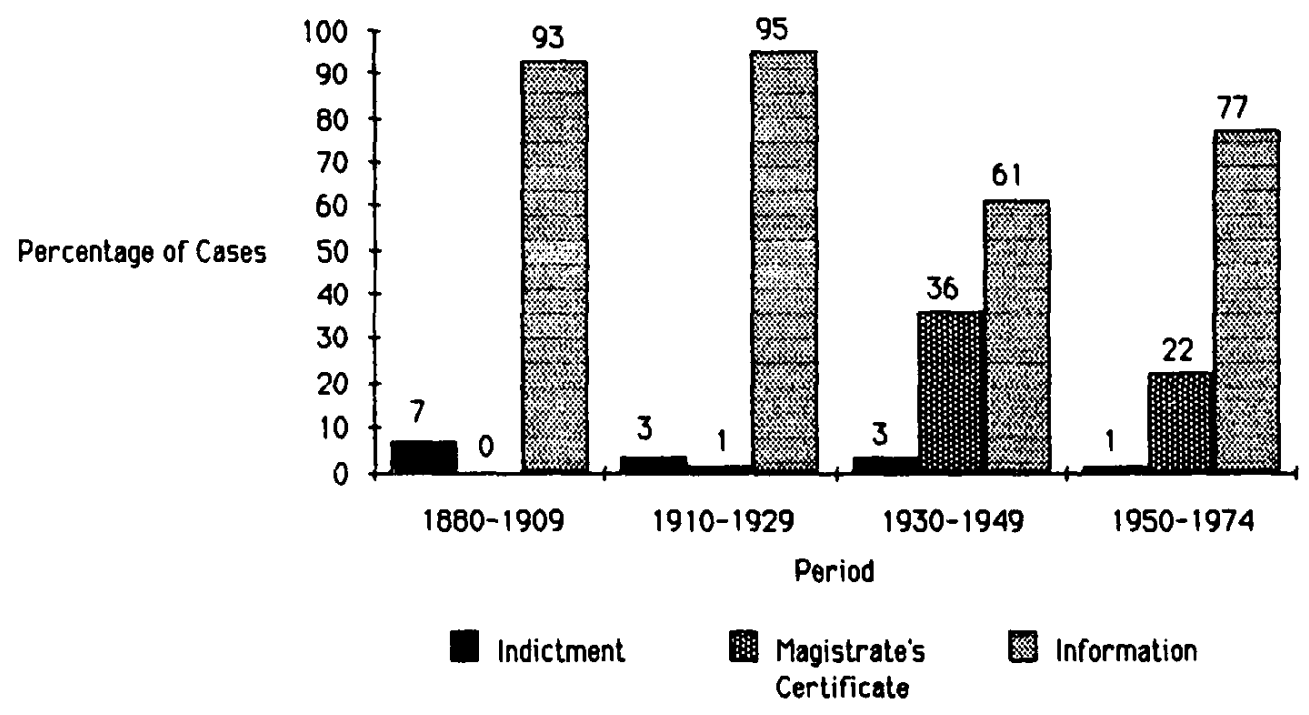

convictions in police and justice courts. There were two judges, one for each department. ${ }^{9}$

The caseload of the Superior Court grew along with the county's population. So did the number of judges; and each judge constituted a 'department'. In 1900 there were five departments. (How these five divided the business among themselves is not easy to tell.) In 1927, there were eight departments. Two of them handled all criminal matters, together with habeas corpus and naturalization proceedings. ${ }^{10}$ In 1955, there were fourteen departments; two of them devoted full time to criminal trials; a third handled juvenile court cases. "In 1970, there were twenty-five judges and departments, plus a full-time court commissioner and referee.

9. 'In some cases, such as trials for capital offenses, and important civil cases, the judges will sit together, and will sometimes, when deemed proper, exchange departments with each other.' Statement of Superior Court Judge A. M. Crane, Oakland Tribune, January $5,1880,3$.

10. Annual Report of the California Judicial Council 38 (1927).

11. Two departments handled civil non-jury trials, six took care of jury trials. One department spent about one-half of its time on domestic relations and the other one-half in hearing short civil trials without juries. The presiding judge, chosen annually from among themselves by the fourteen judges, was the last 'department'. He assigned trial cases among departments, also conducted hearings on 'demurrers, motions and other preliminary matters', and tried civil non-jury cases 'as his time permits'. Alameda County Government (1955), 39. 


\section{The Rate of Prosecution}

In 1860 only 8,927 people lived in Alameda County; in 1970, there were more than one million. In 1880 , the population of the county was 62,976 , according to the federal census. In 1890, the population was 93,864; in 1910, 246,131 ; in 1930, 474,833; in 1950, 740,315; and in 1960, 1,073,184.

The relationship between felony cases and population is set out in Table 2. Cases per 100,000 population declined rather substantially until about 1900. Afterwards the proportion rose, at first slowly, then more rapidly. The ratio for 1955-1964 was no higher than for 1880-1884. Only in the last decade (1965-1974) did the ratio jump significantly.

It is not easy to suggest explanations for this ebb and flow of prosecutions. Obviously, the true 'crime rate' is not the same as the rate of prosecution; and for many crimes-for example, gambling or drunkenness-it makes little or no sense to talk about a 'crime rate' at all. Millions of 'offenses' are committed every year, but enforcement is, and always has been, weak, sporadic, and sensitive to changes in attitudes of the public and the police. ${ }^{12}$ Even for felonies (the more serious crimes), crime rates and prosecution rates shed a rather flickering light on each other. For one thing, each age, and each community, has its own definition of felony or serious

TABLE 2

FELONY CASES AND POPULATION, SUPERIOR COURT, ALAMEDA COUNTY, 1880-1974

\begin{tabular}{|c|c|c|c|c|}
\hline \multirow{2}{*}{$\frac{\text { PERIOD }}{1880-1884}$} & \multirow{2}{*}{$\begin{array}{c}\text { AVERAGE FELONY } \\
\text { CASES PER YEAR } \\
76\end{array}$} & \multicolumn{2}{|c|}{$\begin{array}{c}\text { COUNTY } \\
\text { POPULATION }\end{array}$} & \multirow{2}{*}{$\begin{array}{c}\text { CASES PER } 100,000 \\
\text { POPULATION } \\
\text { PER YEAR }\end{array}$} \\
\hline & & $(1880)$ & 62,976 & \\
\hline $1885-1894$ & 79 & (1890) & 93,864 & 84 \\
\hline $1895-1904$ & 77 & $(1900)$ & 130,197 & 59 \\
\hline $1905-1914$ & 177 & (1910) & 246,131 & 72 \\
\hline $1915-1924$ & 278 & (1920) & 344,177 & 81 \\
\hline $1925-1934$ & 413 & (1930) & 474,883 & 87 \\
\hline $1935-1944$ & 461 & $(1940)$ & 513,011 & 90 \\
\hline $1945-1954$ & 725 & $(1950)$ & 740,315 & 98 \\
\hline $1955-1964$ & 1008 & $(1960)$ & 908,209 & 111 \\
\hline $1965-1974$ & 2046 & $(1970)$ & $, 073,180$ & 191 \\
\hline
\end{tabular}

POPULATION DATA, U.S. CENSUS BUREAU

12. On this point, see Lawrence M. Friedman, 'Notes Toward a History of American Justice', 24 Buffalo Law Review 111 (1974); on police behavior, there is a notable literature, including, for example, Mark $\mathrm{H}$. Haller, 'Historical Roots of Police Behavior: Chicago, 1890-1929', 10 Law and Society Review 303 (1976); Wilbur R. Miller, Cops and Bobbies: Police Authority in New York and London, 1830-1870 (Chicago, 1977); Samuel Walker, Popular Justice: A History of American Criminal Justice (New York, 1980); Robert M. Fogelson, Big-City Police (Cambridge, Mass., 1977). 
TABLE 2A

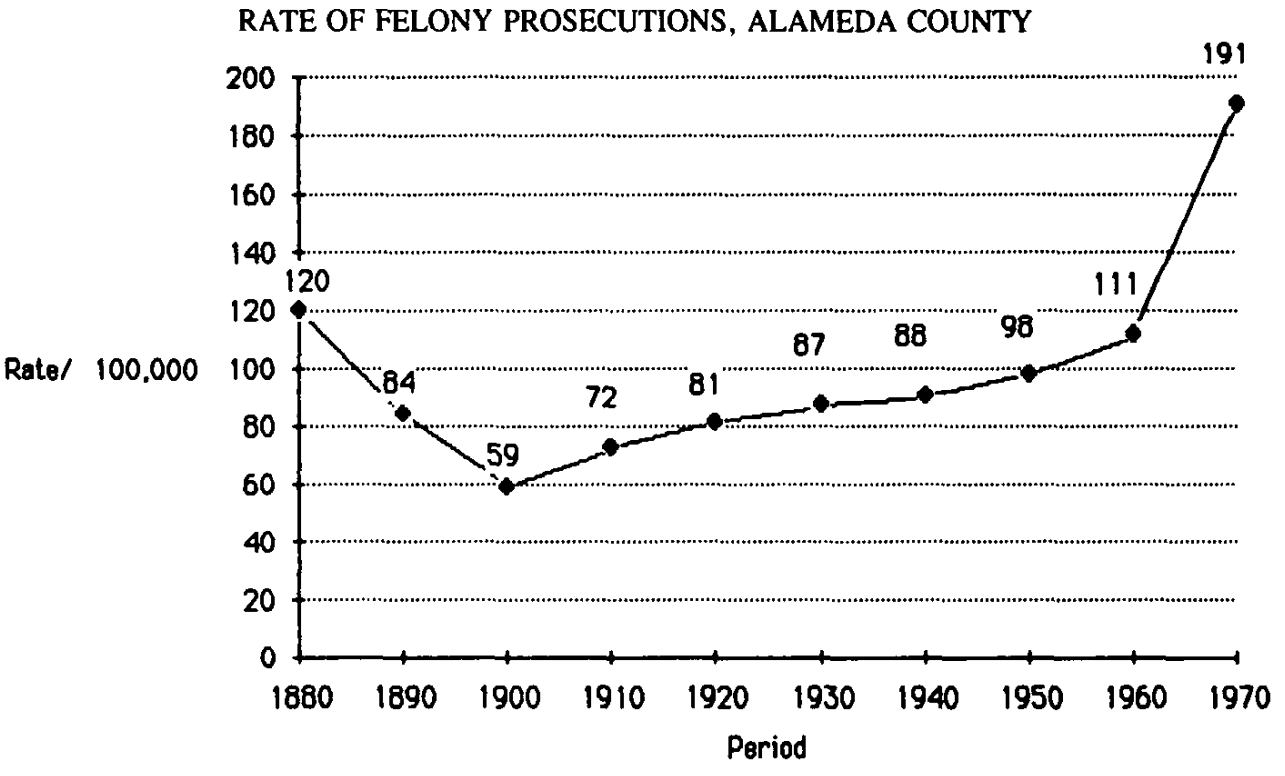

crime; and its own enforcement policy. Rates vary suspiciously from place to place. In 1917, the felony rate in England was reported at 13.5 per 100,000; in Virginia, 104 (for non-liquor offenses).

The Virginia figures rose to 171 by 1928 ; England and Wales meanwhile rose to 21.1; Missouri's rate in 1923-24 was reported to be 218.5 , that of Illinois for $1926,170.3 .13$

On the other hand, scholars agree that, for the most serious crimes, there must be at least some rough correspondence between true crime rates, and rates of arrest and prosecution. Our figures at least suggest, then, that serious crimes declined in Alameda County from about 1880 to 1900 or so; and that the rise in the next two generations was quite moderate. ${ }^{14}$ In the county's early years, the social fabric was loosely-knit at best; strong social institutions were as yet wanting, the population was transient or new. After 1870 , law and order were more or less successfully imposed on the county; life in Alameda became more civilized. But the falling crime rate was not unique to Alameda County. Similar evolution took place elsewhere. Serious crime declined in the 19th century; at some point in the 20th century, social decay apparently set in again. The evidence of other studies suggests that this pattern of fall and rise took place in other countries as well-England, Sweden, Australia. ${ }^{15}$ In Alameda County, drug offenses account for some of

13. Hugh N. Fuller, Criminal Justice in Virginia (New York, 1931) 72-73.

14. Roots of Justice, supra note 4 at 26-35.

15. See Roger Lane, 'Urbanization and Criminal Violence in the 20th Century: Massachusetts as a Test Case', in H. D. Graham and Ted R. Gurr, Violence in America: Historical 
the 'bulge' in felony filings in the 1970s but the figures for crimes against property are also higher than at the turn of the century; prosecutions for crimes against persons have doubled. Since the end of the Second World War there has been, apparently, a tremendous explosion of crime.

\section{Types of Crimes}

What changes have taken place over time in the type of felonies prosecuted? Table 3 sets out the data in brief. This table collapses the time periods into four: $1880-1909,1910-1929,1930-1949,1950-1974$. Table 3a expresses the data of Table 3 in terms of frequencies per 100,000 population.

The Penal Code of California is a formidable document. It lists hundreds of separate crimes and offenses. But most of these make no impact on the docket of the Superior Court. It was, for example, a felony to 'fraudulently produce an infant, falsely pretending it to have been born of any parent whose child would be entitled to inherit . . . with intent to intercept the inheritance'. ${ }^{16}$ It was also a felony to 'wilfully and maliciously sink or set adrift any vessel of ten gross tons and upwards, the property of another'. ${ }^{17}$ Crimes like these were obviously rare, and did not figure at all in the work of police or of courts.

The common crimes have been grouped into six categories: crimes against the person, crimes against property, morals offenses, crimes against public order, drug offenses, and regulatory offenses.

\section{Crimes Against the Person}

Crimes against the person include murder, manslaughter, assault, robbery, rape, and kidnapping. The common factor is violence or the threat of violence. Robbery is included because it involves force, or threat of force, against a person. Rape is a difficult crime to classify.

It can be, and often is a violent crime. But on closer analysis, many rape cases in the sample turn out to be so-called 'statutory rape', that is, cases of intercourse where the female partner was below the age of consent. The age of consent was ten in California until 1889; it was raised to fourteen in that year, to sixteen in 1897, and to eighteen in 1913. The registers do not distinguish between the two kinds of rape, but the great majority of rape cases, in the first half of the period, were, in fact, statutory rape. ${ }^{18}$ In the

and Comparative Perspectives (Washington, D.C., 1969); Ted Robert Gurr, Rogues, Rebels and Reformers, A Political History of Urban Crime and Conflict (Beverly Hills, 1976); Roger Lane, Violent Death in the City: Suicide, Accident and Murder in 19th Century Philadelphia (Cambridge, Mass., 1979); James Q. Wilson and Richard J. Herrnstein, Crime and Human Nature (New York, 1985).

16. California Penal Code 1909, $\$ 156$.

17. California Penal Code 1909, §608c.

18. E.g., Frank B., Crim. No. 9,632, information filed January 21, 1926 (seventeen-yearold girl). 
TABLE 3

TYPE OF OFFENSE CHARGED, ALAMEDA COUNTY SUPERIOR COURT

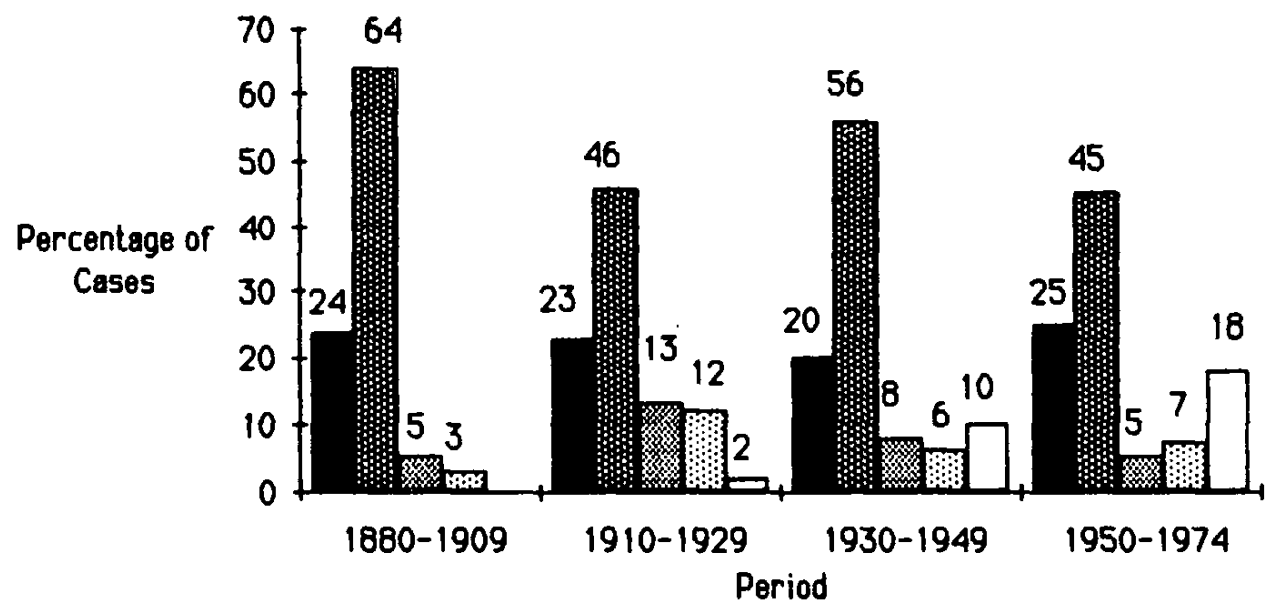

Persons Morals $\quad$ Public Order $\square$ Druqs

TABLE 3A

CASES PER 100,000 POPULATION BY TYPE OF OFFENSE, ALAMEDA COUNTY

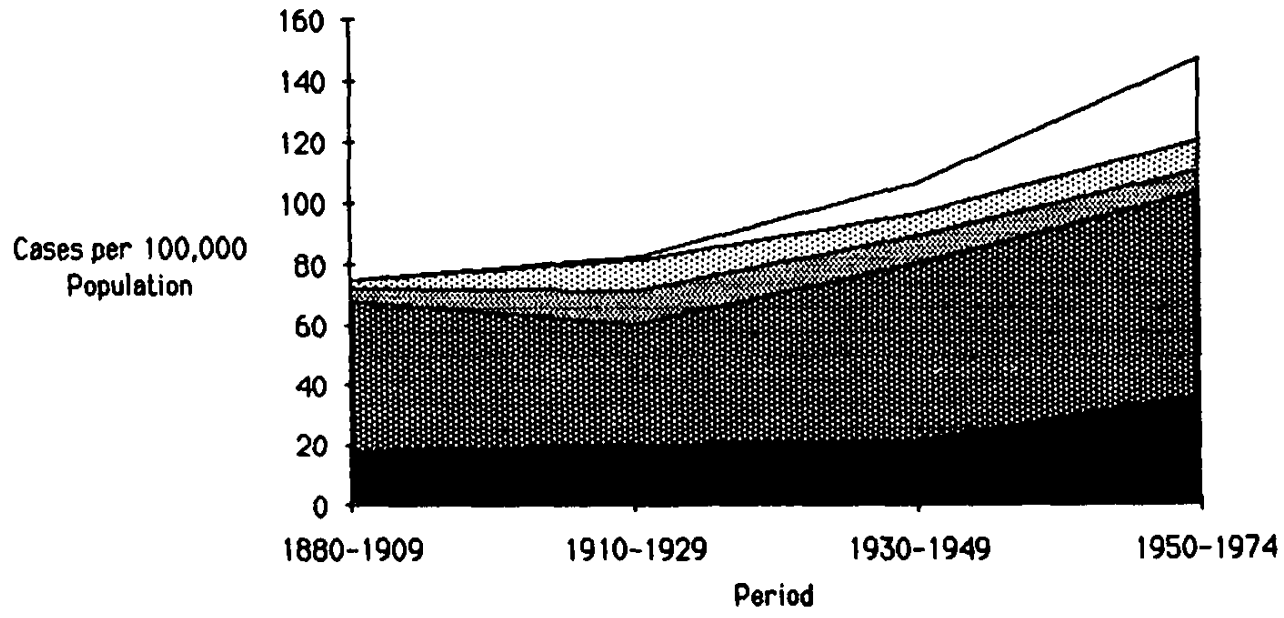

Drugs Mublic Order Morals Property

more recent years, the reverse was true. A careful check of rape cases suggests that for the period 1910-1929, ninety-five percent of the rape cases were statutory; for 1930-1949, eighty-five percent; for 1950-1959, fifty percent; and for 1960-1974, twenty percent. The statutory range of punishments for forcible and statutory rape was the same until 1913; from 
1913 on, there was some provision for leniency when the charge was intercourse with older minor girls. In 1970, statutory rape became the new crime of 'unlawful sexual intercourse' (Cal. Penal Code 261.5), punishable by one to fifty years in prison. Forcible rape (Cal. Penal Code 264) was punishable by not less than three years in prison. (The abolition of indeterminate sentencing, effective July 1, 1977, has since further altered these penalties.) ${ }^{19}$ Under the Code, there were other kinds of non-violent rape-intercourse with a mentally incompetent woman, or one who 'submits under the belief that the person committing the act is her husband, and this belief is induced by . . . artifice, pretense, or concealment' (Cal. Penal Code 261), but these were so rare that they did not affect the sample in any way.

Crimes against the person have contributed a relatively stable share of felony prosecutions in Alameda County-roughly between one-fifth and one-quarter of all prosecutions. Assault once dominated this category (forty-seven percent in 1880-1909). It became thirty-eight percent in the latest period, while the leader in this period was robbery (forty-two percent). ${ }^{20}$ Homicide accounts for only two percent of the prosecutions in the latest period, and only nine percent of all crimes against the person. Assault and homicide are crimes committed by and large, on victims known to the assailant; robbery is a crime against strangers.

\section{Crimes Against Property}

This category includes burglary, theft, forgery, and arson. Property crimes as a proportion of all prosecutions have declined from over sixty percent to about forty percent, though this by no means signifies that property crimes are declining absolutely.

Burglary has been the most frequently charged crime in Superior Court. If any felony defendant could be called 'typical', it might be Albert T., a young man who, on January 23,1923 , pried open a window in the rear of a tobacco shop and stole some goods (Crim. No. 8495). Overall, burglary makes up about sixteen percent of all cases. Theft is another common charge. At one time, it even outstripped burglary. The two crimes often go together: if a man breaks into a house or store, he can be charged with either or both offenses. Theft cases showed a bulge during 1930-1949; otherwise,

19. California Penal Code 1170; on the abolition, see Malcolm F. Feeley, Court Reform on Trial: Why Simple Solutions Fail (New York, 1983) 142-47.

20. It is instructive to compare data for Cuyahoga County (Ohio) Common Pleas Court, for three sample years. (The jurisdiction of this court was roughly equivalent to the Superior Court of Alameda County.) Overall, the figures show great similarity to those of Alameda County, as presented in Table 3. In Cuyahoga County in 1902, for example, property crimes comprised sixty-nine percent of cases while crimes against persons constituted twenty-one percent. In 1935, property crimes were sixty-five percent of the criminal docket, crimes against persons nineteen percent and public order offenses nine percent. In 1970, property crimes were forty-nine percent of the docket, crimes against persons twenty percent, public order offenses nineteen percent and drugs nine percent. 
they have held a fairly stable share of property crimes. Receiving stolen goods amounted to two percent of all prosecutions in 1950-1974, its highest level. This is a difficult crime to detect and to prosecute, which perhaps accounts for its relative rarity. ${ }^{21}$ The case files also suggest that at least some of the defendants were hardly professional fences - certainly this was not true of Frank L., a thirty-three year-old black, who pleaded guilty in 1921 to receiving eight pairs of blankets stolen from the Pullman Company in the West Oakland yard (No. 7805, 1921). Fraud cases are on the decline, while forgery cases have been rising. The popularity of forgery is perhaps to be expected in an age of checks and credit cards. This crime may come to occupy the 'social space' which fraud occupied at the turn of the century.

\section{Morals Offenses}

This is a large and somewhat shapeless category. It includes the so-called 'victimless crimes'. This modern term carries the implication that these offenses are not really serious-a point of view which the population as a whole may or may not share. Morals crimes include gambling, prostitution, various forms of sexual deviance, seduction, and abortion. These crimes are 'victimless' because it is hard to separate the actors out into victims and victimizers. Usually, there is no complaining or prosecuting witness. Both parties may be consenting adults. And it would be unlikely that the victim would complain in a case like that of Juan Cordiel, accused in 1880 of 'the infamous crime against nature, committed with . . . a she goat'.22 Prosecutions for victimless crimes are instigated by police, or by jealous or angry third parties; behind most of these cases lurks some history or explanation, more complex than the story behind the arrest of a thief.

Most charges in this category concern sexual behavior: sodomy, incest, indecency with children. Nonsupport, contributing to the delinquency of a minor, and gambling have also left a mark, with occasional cases of bigamy. Clara K., convicted of this crime in 1922 (No. 8091), was given five years probation and a warning that 'if you have the idea of matrimony in your head, you had better see you are legally divorced from your first husband before you take up your second one'. In recent years, sexual crimes have been the most frequent within this category. But morals cases made up only about one percent of the total prosecutions in the 1970s. Indeed, morals crimes were never a major factor in the docket, and their share has been declining since 1910-1929. The exception is drug offenses, which is treated as a separate category in this paper.

Prosecutions for morals crimes are heavily dependent on police initiative,

21. Carl B. Klockars, The Professional Fence (New York, 1974); Marilyn E. Walsh, The Fence, a New Look at the World of Property Theft (Westport, 1977).

22. Crim. No. 155 (1880). The defendant received an eight year sentence. Of course, not all sex crimes are victimless-certainly not Crim. No. 4057 (1906) ('lewd and lascivious act') where defendant was accused of molesting a ten year old girl. Bigamy and non-support are also morals crimes with well-defined victims. 
and on chance factors. In this category, the relationship between the 'crime' rate, and the rate of prosecutions, is exceptionally weak. The data shed no light at all on the amount of illegal sexuality. Moreover, the Superior Court deals only with felony cases. Gambling and prostitution loomed quite large in the work of petty criminal courts, but were poorly represented at the felony level. A complete analysis of all cases in Superior Court in 1910 did turn up ten prosecutions for violating \$377a of the (then) Penal Code, which provided for punishment (either as a felony or a misdemeanor) for anyone who 'engages in poolselling or bookmaking', or who handles bets 'upon the result of any trial or contest of skill, speed or power of endurance, of man or beast'. During the same year there was one prosecution for 'placing one's wife in a house of prostitution', and one prosecution for contributing to the delinquency of a minor. There were no less than eight prosecutions for violations of Penal Code 270-wilful failure to provide food, clothing, shelter, or medical care for a child.

\section{Crimes Against Public Order}

In this category we have gathered a rag-bag of crimes-weapons violations, traffic crimes, reckless or drunk driving, bribery, perjury, election fraud, escape, resisting an officer, riots and threats. Here belong such men as Harry Regis, charged with cutting a hole in the ceiling of the bathroom of the Oakland City Prison on February 19, 1910, in an attempt to get out-an act which netted him a year and a half at Folsom Prison (No. 4735,1910 ). In the 1920 s, traffic offenses (drunk driving, above all), made up about fifteen percent of the court cases. In the latest period, traffic offenses dropped to about one percent of prosecutions. Of course, here too the lower courts played an essential role. Enormous numbers of minor traffic offenses were processed by them every year. If we exclude traffic cases, we find that prosecutions for crimes within this category have increased slowly over the years. In the 1970s escape and weapons violations were the most frequent charges.

\section{Drug Offenses}

There were no prosecutions for drug offenses in the earliest years of the court. Drug abuse became a criminal offense only in the twentieth century. ${ }^{23}$ In 1907, the legislature passed an 'act to regulate the role of poisons', which prohibited the 'sale of morphine, codeine, heroin, opium and cocaine',

23. As early as 1899 , however, the legislature enacted a statute forbidding any unathorized person from bringing any 'opium, morphine, cocaine, or other narcotics', or liquor or firearms, onto the grounds of state prisons or reformatories. California Penal Code $1909, \$ 180 \mathrm{a}$. On the history of drug laws, see David F. Musto, The American Disease: Origins of Narcotic Control (New Haven, 1973); Troy Duster, The Legislation of Morality: Law, Drugs and Moral Judgment (New York, 1970). 
except by prescription. ${ }^{24}$ A law of 1929 proscribed possession and sale of cocaine, opium, heroin, morphine, and 'leaves of hemp or loco weed cannabis sativa', that is, marijuana. ${ }^{25}$ Drug offenses began to make a mark on the docket in the 1920s. Many of the defendants in the 1920s had Mexican surnames. A certain Roy M. (Crim. No. 10,670), sentenced to thirty days in jail in 1928 for possession of marijuana, and George E., who got a year for 'unlawful sale of a preparation of Indian hemp', in 1938, were forerunners of a vast army of defendants. Drug cases have increased their share of the caseload enormously in recent years. For 1970-74, drug offenses amounted to nearly one-fifth of the cases in our sample of Superior Court cases; in 1971, according to a State report, drug offenses accounted for thirty-eight percent of all adult felony arrests in Alameda County. ${ }^{26}$

In recent years, California has taken some of the sting out of drug laws. Certain felonies have been downgraded into misdemeanors. ${ }^{27}$ In any event, enforcement, especially of marijuana laws, has often been sporadic. Many people resent a process which labels users as criminals, especially when the laws of the land snap shut on more and more members of the middle class. ${ }^{28}$

\section{Regulatory Offenses}

This category includes violations of laws regulating business, tax laws, license laws and the like. It has never been a large category; few prosecutions ever fell into this class. At one time the most common crime in this category was illegal use or possession of a still. After Prohibition ended, this crime lost its importance.

\section{Characteristics of Defendants}

The Register of Actions of the Superior Court was the primary source of data on felony cases. The Registers do not provide much information about the background of defendants - age, race, income or social class. Indeed, even the raw files often lack this information. For the period 1872-1910, arrest records of Oakland provide a certain amount of background information. The first names of defendants, moreover, make it possible to tell

24. California Laws 1907 , ch. 102, $\$ 8$. 'Preparations of opium containing less than two grams of opium to the fluid ounce' were excepted.

25. California Laws 1929, ch. 216.

26. California Comprehensive Data Systems, Criminal Justice Profile for Alameda County, Department of Justice, Division of Law Enforcement, Bureau of Criminal Statistics, Sacramento, California, 1975.

27. See Health \& Safety Code $\$ 11,000$; California Penal Code $\$ 1000-1000.5$ (both adopted in 1972).

28. See John Kaplan, Marijuana, The New Prohibition (New York, 1970). 
whether defendants are men or women, in almost all cases. ${ }^{29}$ Throughout the period women as sole defendants were a very small percentage of the population accused of crime-between four and six percent. The proportion of cases with female co-defendants may have risen slightly since 1950 (to about three percent). Most of these are drug prosecutions.

Not much work has been done on the crime rates of women, or on the way women are handled by the criminal justice system. ${ }^{30}$ All studies agree that women do not figure heavily in felony prosecutions. A preliminary analysis of sex of defendants for Cuyahoga County, Ohio (Cleveland), for the period 1810-1899, also based on a sample of felony cases, shows a slight rise in the number of women defendants in the course of the nineteenth century. There were virtually none in the earliest period, and about ten percent at the end.

Because there are so few women defendants in the sample it is hard to generalize about charges brought against women. Women are almost never accused of burglary. Homicide is their main violent felony, and it is rare. Women are charged with assault, but these cases do not reach Superior Court, except in the rarest instances.

\section{Type of Attorney}

Table 4 provides some data on the use of attorneys by defendants in Superior Court. The rise in public defenders is very striking. Alameda County created the office of public defender in $1927,{ }^{31}$ somewhat later than other major counties in California. ${ }^{32}$ In 1927, there was a single public defender, who, together with his deputy, made 883 court appearances, and handled 285 cases. The office grew until, by 1963, it employed thirteen attorneys, two investigators, and was handling over 4,000 cases per year. ${ }^{33}$

29. A few first names are ambiguous, and the first names of Chinese defendants, as romanized, do not provide reliable information on sex. But in the early years the Chinese population was overwhelmingly male-92.4\% in 1900-and one can safely assume that nearly $100 \%$ of Chinese defendants were male. See Walter G. Beach, Oriental Crime in California (New York, 1932) 11. In any event, any errors here would alter the results only in minor ways.

30. On women in prison, see Estelle B. Freedman, Their Sisters' Keepers, Women's Prison Reform in America, 1830-1930 (Ann Arbor, 1981).

31. County of Alameda Charter, sec. 27 (1927).

32. The first public defender's office was set up in Los Angeles County in 1914, by county charter; and the city of Los Angeles followed in 1915. The legislature expressly authorized counties to establish public defender offices in 1921, Cal. Government Code, Sec. 27700; San Francisco immediately took advantage of the law. There was, apparently, widespread dissatisfaction with the assigned counsel system. 'The Public Defender', 3 California Law Review 314 (1915); see also Mayer C. Goldman, The Public Defender (New York, 1974) 15-23.

33. Jerome H. Skolnick, Justice Without Trial, Law Enforcement in Democratic Society 
TABLE 4

REPRESENTATION OF DEFENDANTS IN SUPERIOR COURT, ALAMEDA COUNTY

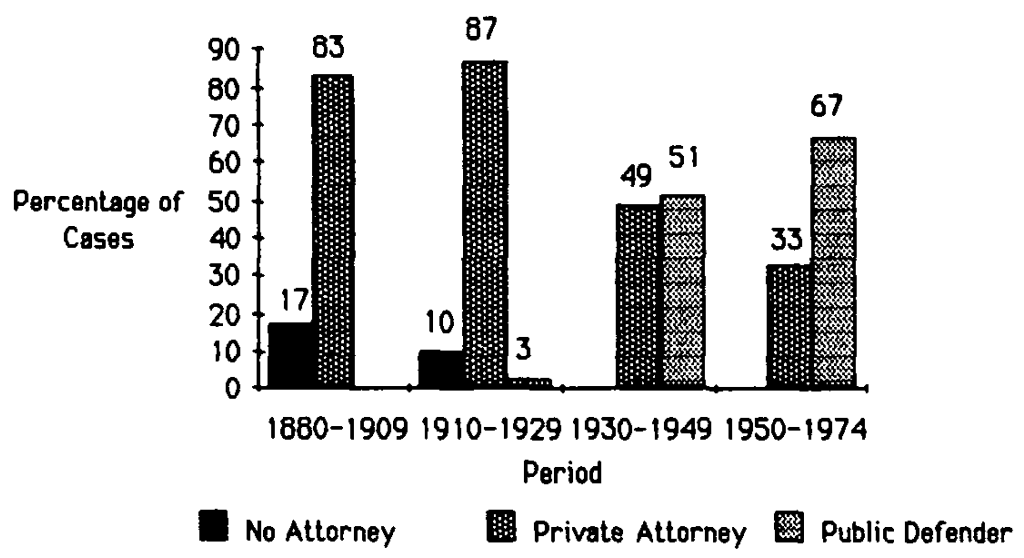

In our sample, for the period 1950-1974, the majority of defendants (sixty-two percent) were represented by public defenders. ${ }^{34}$

Table 4 makes very clear that Alameda County defendants have usually had a lawyer. Defendants did without counsel most commonly in the years before 1930; but even then close to nine out of ten of our sampled defendants had some sort of lawyer. After 1930, counsel was almost universal. The California Penal Code, from 1872 on, gave a right to counsel, and insisted that the defendant 'must be informed by the court' of this right, 'before being arraigned', and must be 'asked if he desires the aid of counsel'. If the defendant could not afford a lawyer, the court had the duty of assigning one. ${ }^{35}$ Few defendants in fact waived counsel.

There is ample evidence in the files to show that judges took their duty seriously, at least to the extent of reminding defendants of their rights. There is little data about assigned counsel, however; and for many defendants we do not know if their lawyers were assigned, or were privately chosen and paid. Some of the private attorneys, at least in the

(New York, 1966) 260-62. This is a study of the police in Oakland (disguised as Westville), and the figures are for the public defender's office in Alameda County (disguised as La Loma County).

34. See Table 4.

35. California Penal Code $\$ 987$ (enacted in 1872): 'If the defendant appears for arraignment without counsel, he must be informed by the court that it is his right to have counsel before being arraigned, and must be asked if he desires the aid of counsel. If he desires and is unable to employ counsel, the court must assign counsel to defend him.' 
early years, were sometimes marginal lawyers, who hung around criminal courtrooms trying to pick up crumbs of business. Nevertheless, the figures are striking. Apparently it was never true in Alameda County that felony defendants went through the process in Superior Court without some help from a lawyer.

Whether that help was worth much is another question. And it may have come at a rather late stage of the proceedings. For most of the period, there was no right to (appointed) counsel at the stage of preliminary examination. This was the state of the law, and transcripts of proceedings in Justice Court make clear that it was the practice as well. In 1924, for example, a twenty-seven-year-old was charged with molesting a nine-year-old girl. In Justice Court, the judge asked him: 'Do you desire to get an attorney'? Defendant said, 'I have got no money, and I have got no friends'. The judge replied, ' . . we will put this over for a few days, and if you can get an attorney all well and good; and if you cannot the district attorney's office or the Court will see whatever rights you have are protected here, and if you should be held over to the Superior Court for trial, the Superior Judge will then appoint someone to act as your attorney'. ${ }^{36}$

The California courts consistently declined to declare this arrangement unlawful. ${ }^{37}$ Only in 1951, in an age of heightened awareness, was the Penal Code (\$859) amended to give the defendant the right to counsel at preliminary hearings, when the defendant faced felony charges.

From about 1930 on, public defenders competed with private and appointed attorneys. According to Jerome Skolnick, writing in the 1960s, public defenders were 'acknowledged, sometimes grudgingly, to do able work, comparable to that of the private defense attorneys in the area' ${ }^{38}$ But other sources suggest that public defenders do not have a good reputation with defendants. ${ }^{39}$ Our data do not permit us to draw sharp distinctions between the quality of work of different types of attorney. Public defenders represented clients most often for property crimes, less frequently for crimes against persons, rarely for other types of crime. Their clients pleaded innocent less often than those of private attorneys, at least as an initial matter; they more often pleaded guilty as charged. Thirty-eight percent of their clients simply gave up and pleaded guilty as charged. These cases are

36. Transcript, Proceedings in Justice Court, City of Alameda, in Crim. No. 8711 (1924) (emphasis added). See also Judah B., No. 6360 (1916): the defendant said to the judge at preliminary examination, 'I believe you have the power to assist me in obtaining an attorney who will appear for me'. The judge said, 'I can continue the matter . . . and try and see if I can get some attorney . . . I can't compel an attorney to appear for you, it is simply by solicitation.'

37. People v. Crowlay, 13 Cal.App. 322, 109 Pac. 493 (1910); People v. Campos, 10 C.A.2d 310, 52 P.2d 156 (1954).

38. Jerome Skolnick, Justice Without Trial (New York, 1966) 262.

39. See Lynne N. Henderson, 'The Wrongs of Victims Rights', 37 Stanford Law Review 937, 1003 (1985); Jonathan D. Casper, American Criminal Justice: The Defendant's Perspective (Englewood Cliffs, 1972) 100-17. 
essentially uncontested, but we do not know whether an informal bargain on sentence had been struck, or whether we are in the presence of implicit plea bargaining..$^{40}$ The clients of public defenders also change their plea to guilty of a lesser offense, or to fewer counts, more often than those of private attorneys do. This suggests a high rate of plea bargaining. The two types of attorney win similar proportions of dismissals.

When it comes to sentencing, clients of public defenders do not do as well as those of private attorneys. They get jail or prison more often than clients of private attorneys; they win pure probation less often. The kind of defendant, the charge, or the circumstances of the case may explain the difference. Cases are not randomly assigned to public defenders and to private lawyers. Public defenders perhaps get the more hopeless cases. They certainly get the defendants who are poor or down-and-out.

\section{Bail}

Over the period covered by this study, more and more defendants in Superior Court were able to get some form of pretrial release (bail or release on recognizance). In the earliest period, only eight percent of the defendants won pretrial release; by 1950-1974 this had risen to forty-seven percent. However, during the 1930s and 1940s, the proportion fell to twenty-three percent from thirty percent during the 1910 s and 1920 s. In this period, a number of indicators suggest that defendants were treated more severely than before or after.

In the early years, a defendant who wanted bail probably tried to get relatives or friends to 'go surety'. As early as 1900 , there were some professional bondsmen-businessmen who went surety for pay. In 1898-1899, for example, we find a 'merchant' named W. M. Watson listed as surety in two unconnected cases. S. S. Osgoode, a druggist, is another name that pops up in the records over the years from about 1900 to 1920. In the 1920 s, there are many references to professional surety companies the Globe Indemnity Company and the New Amsterdam Casualty Company. The professional bondsman is standard today.

Bail has been set at higher and higher amounts since 1880. The dollar in the 1970s bought less bail as well as less bread than the 1880 dollar. Average bail (see Table 5) roughly tripled between 1880 and 1970; so did the consumer goods price index of the Department of Labor. Naturally enough, the more serious the crime, the higher the bail. The average bail for defendants who ended up in state prison was higher than bail for those who ended up in county jail $(\$ 11,473$ compared with $\$ 2,870)$. Interestingly, judges set lower bail amounts for defendants who pleaded guilty, compared to those who pleaded not guilty and then changed their plea $(\$ 3,225$ and

40. Milton Hermann, 'A Note on Plea Bargaining and Case Pressure', 9 Law \& Society Review 515 (1975). 
TABLE 5

AVERAGE AMOUNT OF BAIL IN CASES IN WHICH BAIL ALLOWED

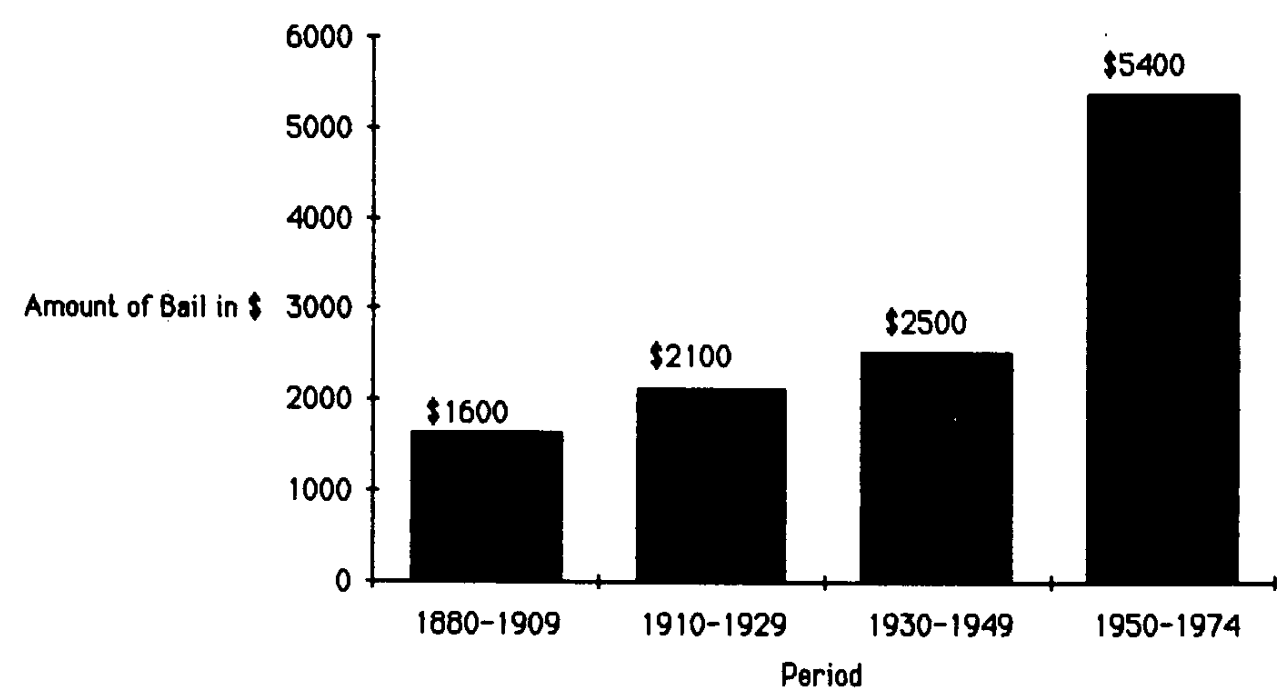

$\$ 5,492$, respectively). Bail may be one of the 'goods' which defendants and their lawyers can bargain about.

\section{Pleas}

The guilty plea has become more and more frequent in Superior Court over the years. This is especially so when we add together initial and ultimate pleas of guilty. In the latest period (1970-74), over half of all defendants (fifty-one percent) changed their initial plea of not guilty to a plea of guilty. Thirty-six percent pleaded guilty to fewer or lesser charges; fifteen percent changed their pleas to guilty as charged. In this period, seventy-three percent of all defendants pleaded guilty at one stage or another. The percentage of initial guilty pleas has, however, first risen and then fallen. In the nineteenth century, most defendants (over three-quarters) entered a plea of not guilty, and relatively few changed their plea. The guilty plea rose steadily; it constituted fifty-seven percent of original pleas in 1940-1949. In the latest period of study (1960-1974), most defendants again pleaded innocent (sixty to eighty percent), but, as we noted, it was common to change pleas later on. There is no mystery to the pattern. The results of the period after World War II reflect the pervasiveness of plea bargaining. Plea bargaining can be found from the very beginning in Superior Court, ${ }^{41}$ but it did not dominate the process until the most recent period.

41. Roots of Justice, supra note 4 at 175-78; Lawrence M. Friedman, 'Plea Bargaining in Historical Perspective', 13 Law \& Society Review 247 (1979). 
TABLE 6

CASE DISPOSITIONS

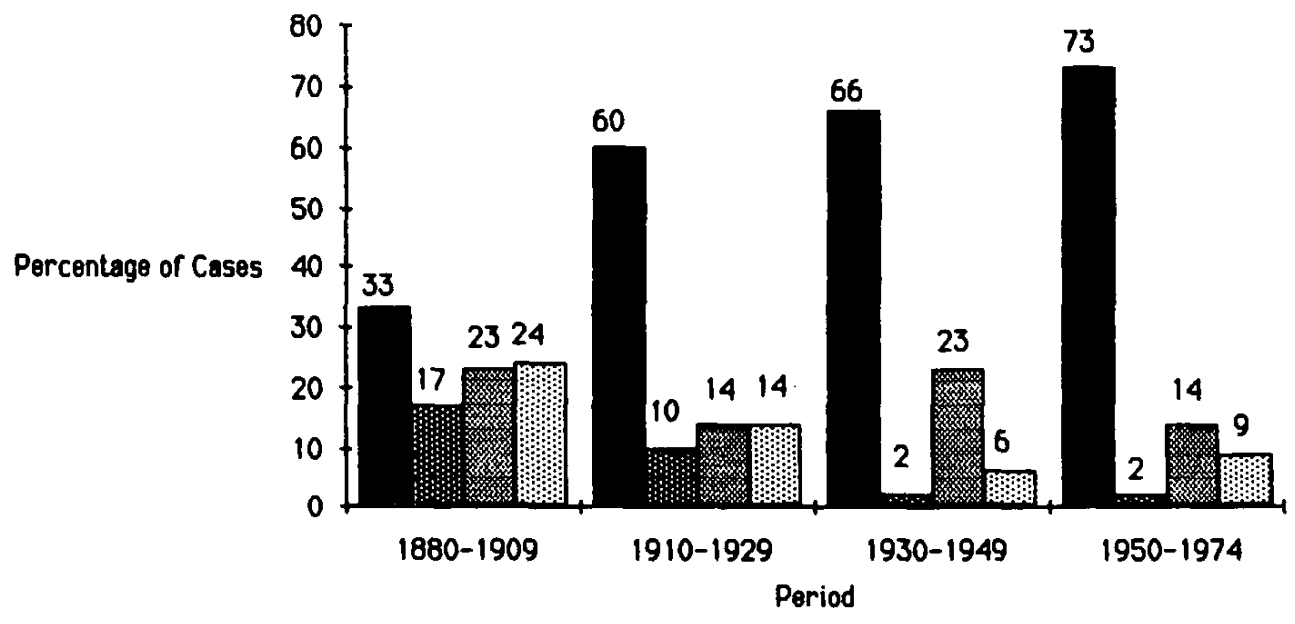

Pleaded Guilty Acquitted Convicted Dismissed

VIII. Dispositions

Table 6 shows in summary form how cases in Superior Court were disposed of between 1880 and 1974. A fair number of cases in each period were dismissed, usually on motion of the district attorney, and the records rarely reveal the reasons. The district attorney may simply decide he has no case. ${ }^{42}$ Sometimes the case is quietly dropped, but the record and file do not show a formal dismissal; Kate McCarthy, in 1881, was charged with perjury (Crim. No. 245); she posted bond, went free on bail, and that was the end of the case. Other dismissals came about as a result of plea bargaining. The dismissal rate was lowest in 1930-1949. Of course, many cases were dismissed by magistrates and never reached Superior Court at all.

As we noted, since early in the century, the guilty plea has disposed of the majority of the cases, in one way or another. Since 1930, two-thirds or more of the dispositions have come about through guilty pleas (see Table 6). The percentage of cases that went to trial dropped steadily. So too of the number of acquittals. In the latest period, sixteen out of every one hundred

42. See Oakland Tribune, November 5, 1883, 2, 'A Chinese Conspiracy'. According to the story, a 'Chinese cucumber picker . . . was murdered on Jones' ranch'. A man was arrested, on the testimony of Chin Ah Cheung. But the defendant convinced the court that Chin was lying, trying to frame the defendant and inherit his young wife. The magistrate let the defendant go, and Chin was arrested, 'on a charge of perjury, but the District Attorney, not being certain that he had sufficient evidence to convict, ordered his discharge'. 
VERDICT OF FIRST TRIAL, ALAMEDA COUNTY SUPERIOR COURT

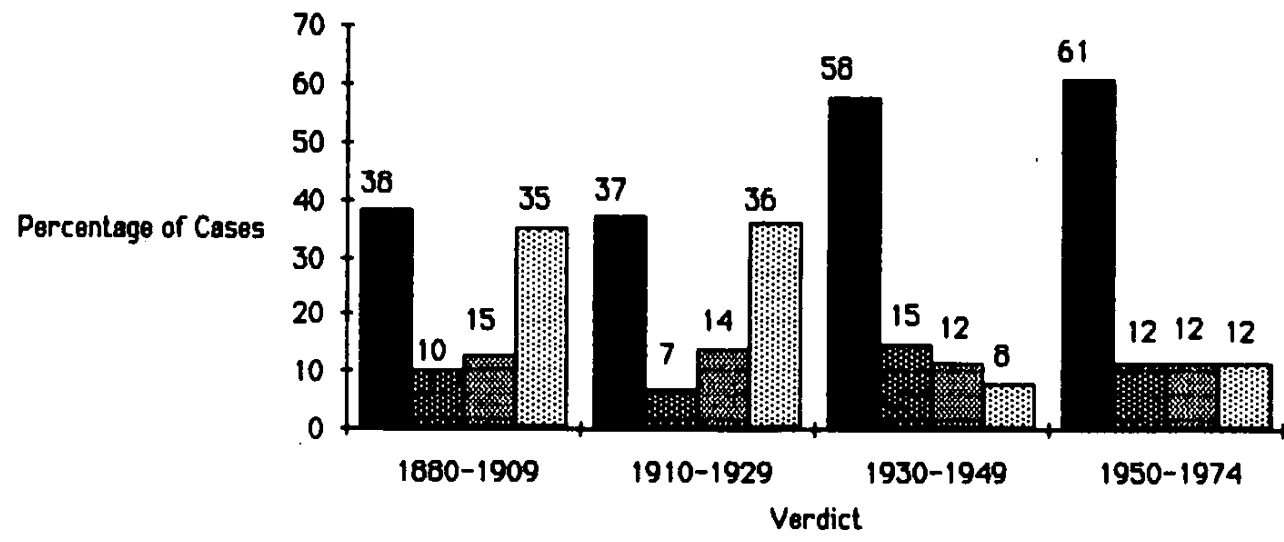

Guilty Guilty of Lesser Hung Jury

defendants charged with a felony went to trial. Only two percent won acquittal. Defendants are far more likely to go free because of a dismissal than because a jury believes their story. And a trial has never been the norm in Superior Court, not even in 1880 . For most defendants, the ultimate outcome has been administratively determined, rather than by judge and jury. This trend became more pronounced over the years.

Before the 1930s, 'trial' meant solely trial by jury. Beginning in the 1930s, non-jury trials (so-called bench trials) became more frequent. Bench trials tended to be used for less serious cases than jury trials-for example, cases of forgery, gambling, traffic violations, receiving stolen goods, and contributing to delinquency; and drugs and weapons cases. As one might expect, jury trials took longer than bench trials; they averaged 3.1 days, while bench trials averaged 1.4 days.

Bench trials, in Alameda County, seemed to result overwhelmingly in convictions. Throughout the history of the Superior Court, juries acquitted about thirty percent of the time. Bench trials resulted in acquittal slightly more than ten percent of the time. Bench trials in Alameda County were less favorable to defendants than was true in the rest of the state. Thus, in the biennium ended June 30, 1946, there were 133 convictions in bench trials in Alameda County, and only sixteen acquittals. Statewide, there were - 2,360 convictions, and 869 acquittals in bench trials-roughly twenty-five percent, considerably better than the eleven percent in Alameda. Juries, in this biennium, were more inclined to acquit: there were forty-four acquittals, and 129 convictions in Alameda County. ${ }^{43}$ But types of cases which go to

43. Biennial Rpt., Att'y Gen'l Cal. (1946), pp. 58-59. Lief H. Carter, The Limits of Order 
TABLE 8

TYPE OF SENTENCE AS PERCENTAGE OF ALL SENTENCES

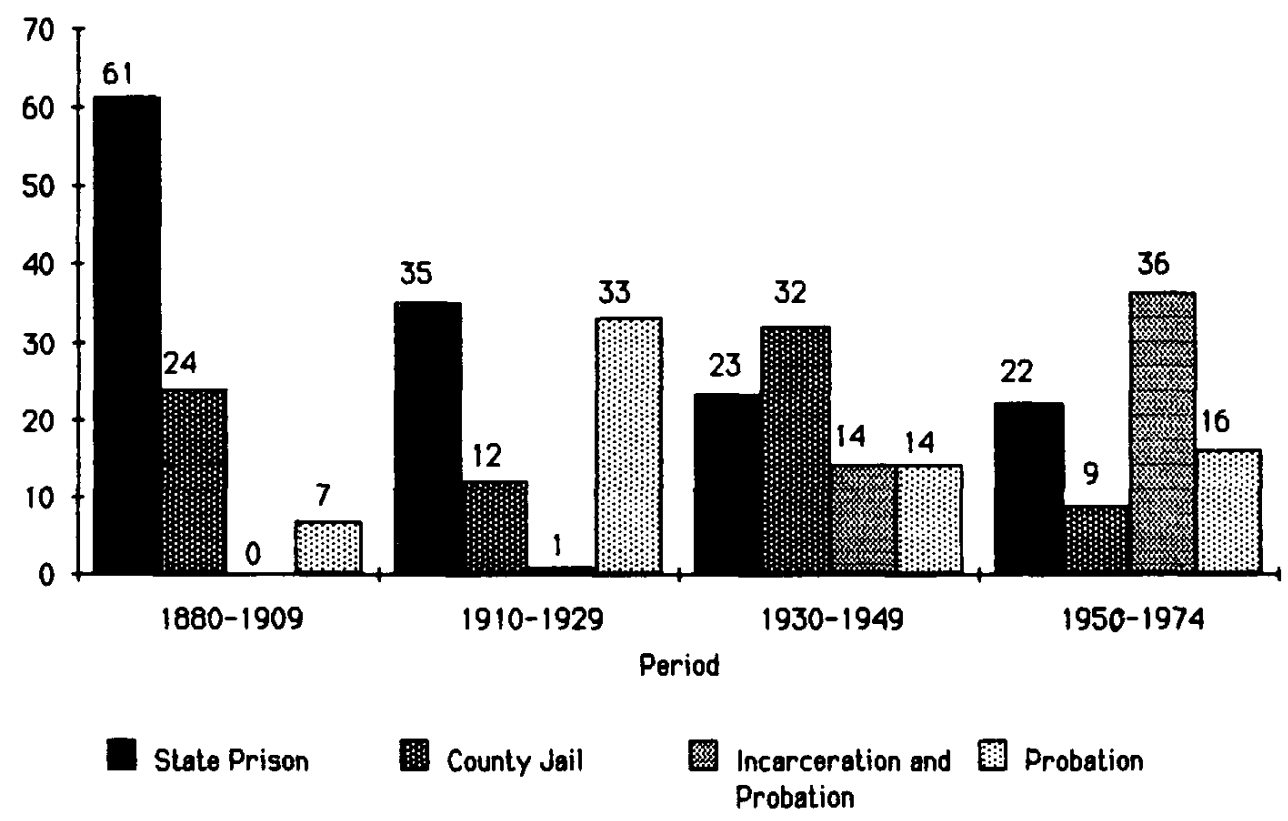

judge rather than jury may vary systematically. Studies of jury behavior suggest that juries are more lenient than judges; that a judge would deal more harshly, or at least acquit less often, than a jury; our data are not inconsistent with this finding. ${ }^{44}$

\section{Sentences}

Sentencing policy has changed greatly between 1880 and the present. At first, the law provided for relatively long, fixed jail and prison terms. Later came the indeterminate sentence and supervised release. The indeterminate sentence was used in Massachusetts as early as the 1880s. It became law in California in 1903.45 Table 8 shows what happened to sentences. Sixty-one

(Lexington, Mass., 1974) 161, reports that only ninety-seven-about ten percent of 965 felonies prosecuted in the county in 1960 , went to trial before a jury. The defense won twenty-eight of these. There were thirty bench trials, and the defense won one-half.

44. Harry Kalven and Hans Zeisel, The American Jury (Boston, 1966).

45. California Penal Code sec. 1203 , enacted in 1872 , gave the judge the right to take into account, at a summary hearing, and on the suggestion of either side, 'circumstances . . . either in aggravation or mitigation of ... punishment'. The law was amended in 1903, to give the judge power to grant probation to defendants over sixteen, 'if it shall appear by the record furnished by the probation officer' that there were 'circumstances in mitigation of the punishment'.

The section was further amended in 1911 . The 1911 changes made more explicit the process of referring the case to a probation officer, who would investigate and report, 'recommending either for or against release upon probation'. 
TABLE 9

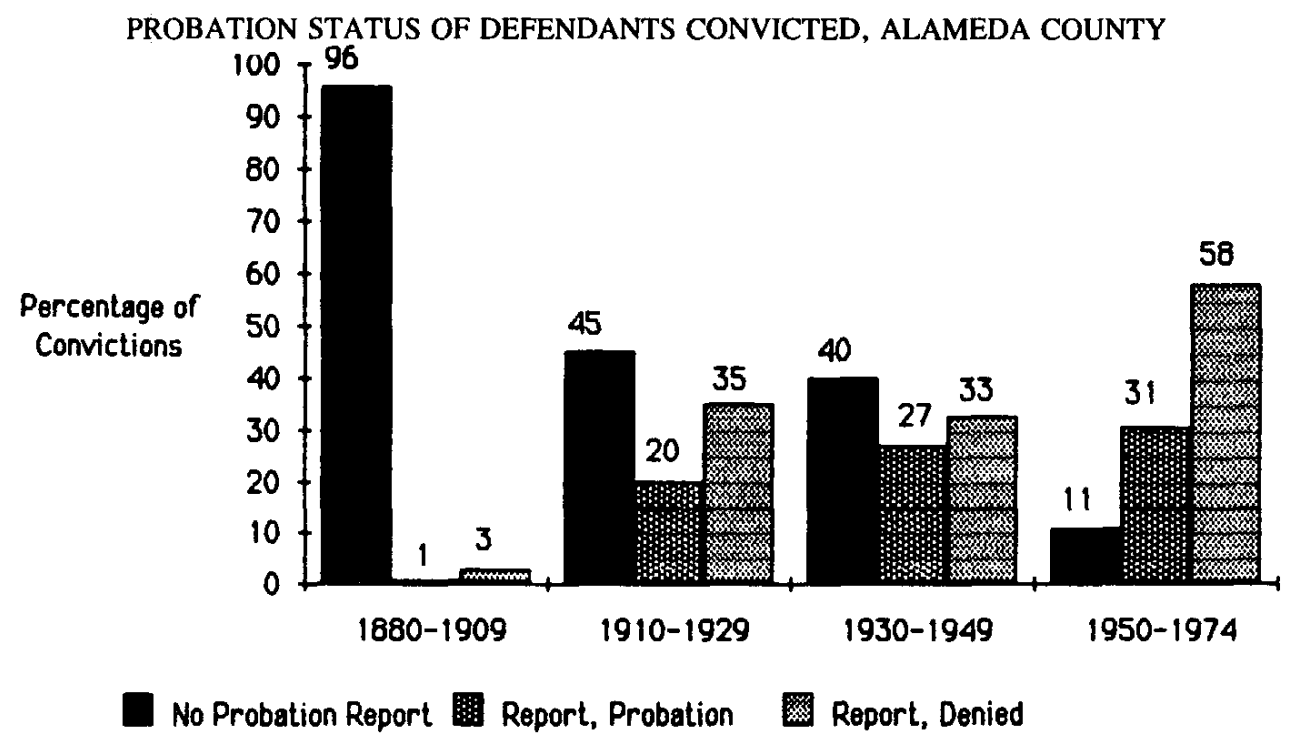

percent of all those convicted in 1880-1909 were sentenced to state prison. By 1930, this percentage had dropped to twenty-three percent, and this proportion remained virtually unchanged during the rest of the period of the study. The percentage sent to county jail has fluctuated. In 1974, it was at its lowest point. Sentences which combined jail and probation rose dramatically, and by the 1970s were over a third of all sentences. This was, for example, the fate of Fred D. (Crim. No. 15453), who was convicted of grand theft in 1938, and given six years probation, 'to serve the first seven months of said probation in the County Jail'. Interestingly, defendants were less likely to be released in the 1970s on probation than in 1910-1929, and by a substantial margin.

As the table shows, probation has become a significant element in sentencing. 1910-1929 was the first of our period in which probation was in widespread use. Over the years, it has become fairly routine to call for a probation report (Table 9). In the earlier years, judges sometimes denied a request even to refer a case to a probation officer. ${ }^{46}$ And as Table 9 shows, probation was often denied, usually because the report itself recommended against probation. From the very beginning, judges have tended to go along with the recommendations of the probation officers.

From our records, we are unable to say much about sentences actually served by prisoners. In 1914 the indeterminate sentence entered California law. Under this statute, the Board of Prison Directors fixed sentences, on recommendation of the Board of Prison Terms and Paroles. Sentences were to be fixed after the convict arrived at the prison. The Superior Court Clerk would duly note this sentence, and record it in the Register. But from 1944

46. See, for example, Crim. No. 8711 (1924). 
until 1976, ${ }^{47}$ the California Adult Authority set sentences. The practice of the Authority was not to fix the term, until the prisoner served out his minimum period. Often, the Authority set no expiration date at all, and released prisoners only when it approved an application for parole. The various dates and figures never found their way into the Registers; hence, for cases after 1944, the 'sentences' are not known in any meaningful way.

Superior Court judges did fix sentences, but only in less important cases; in serious cases, power had drained out of their hands, into those of the Board of Prison Directors, and afterwards, the Adult Authority. The judge could still grant probation, of course. If he did not, the most he could do was make a record that might influence the parole board. So, in a burglary case (James C., No. 7463) in 1920, the deputy district attorney praised the defendant for helping recover stolen property, and in prosecuting a fence. 'In view of the fact that Your Honor cannot [fix sentence], and the law requires an indeterminate sentence, I am making this statement so that it will be in the record that goes up, so that the parole authorities may have it for what it is worth'. The Judge agreed: 'I feel just as you do . . . in the matter. If I was in a position to fix the term of imprisonment, it would not be a long one at all; it would be, in fact, a short one'. The defendant was sent to San Quentin.

Thus it is hard to tell the effect of the indeterminate sentence on actual time served. In California, the President of the State Board of Prison Directors claimed in 1921 that the Board was setting stiffer sentences than under the old regime. Sentences were twice as long for rape (twenty years and six months, as opposed to nine years and eleven months, on the average). For other crimes the differences were smaller (two months, for burglary), but almost invariably more severe. .8

Table 9 shows us that less than half the convicted defendants with probation reports were actually put on probation. The records do not show explicitly whether the judge usually or invariably followed the recommendations. It is likely that judges as a rule took up whatever the probation report suggested. As Raymond Moley remarked in 1930, probation, originally 'a means for the control of delinquents who had been found guilty and who were permitted to remain at large in lieu of imprisonment', had come to mean 'a sort of intelligence bureau to aid the court in dealing with defendants. A probation department ... makes recommendations which the judge almost invariably follows in granting probation. 49

The more serious the charge, or course, the harsher the sentence. About half of those convicted of murder were sentenced to death. The rest were

47. California Penal Code, $\$ 1170$, effective July 1,1977 , abolished the indeterminate sentence.

48. These figures are quoted in Robert H. Gault, 'The Indeterminate Sentence Law a Success', 12 Journal of the American Institute of Criminal Law and Criminology 5 (1921).

49. Raymond Moley, Our Criminal Courts (New York, 1930) 162-63. 
sent to prison, for terms averaging more than twelve years. Robbery defendants, for example, averaged sentences of four years in prison when convicted; defendants convicted of assault were likely to be sent to county jail. About half the convicted burglars went to state prison; their average sentence was thirty months.

\section{Conclusions}

The study of crime and punishment in Alameda County, which this essay is a portion of, was inspired in part by the sense that so many pages in the history of crime and punishment were blank, and needed, above all, a solid base of facts and figures to fill them in. This essay does present some facts and figures; but we are aware that facts and figures do not speak for themselves, historical facts and figures perhaps least of all. Our tables and graphs probably raise more questions than they answer.

The data do not tell us, for example, whether the experience of Alameda County was typical, and, if so, typical of what. Alameda County may not be a fair sample of California, let alone the country (or world) as a whole, even for its period. This, of course, is the classic problem of the casestudy. The only answer to the skeptic is, Go thou and do likewise, and if possible somewhere else. Until other case studies are published, we have to assume that the patterns of crime and punishment in Alameda County are roughly typical for the state, country, and period. But this is hypothesis, not demonstrated fact.

What do we learn from the data? We learn something about the road down which the system has been traveling. Partly, this is a road toward increased professionalization. By this we mean that decisions are more and more in the hands of people who work full-time within the criminal justice system. This includes the police, public defenders, probation officers, and prosecutors. Less and less is the fulcrum of decision in judge and jury. This process had already gone quite far by 1880 ; it has gone even further since. As a consequence, the typical felony case deviates greatly from the model or ideal of (full) trial by jury. The guilty plea-usually reached after plea bargainingemerged in the course of time as the dominant means of case disposition. There was plea bargaining in 1880; but it was much less common than in the 1970 s, and was by no means pervasive in the early years.

The data also bear on the general question of the rates of commission of serious crime. Clearly, these rates, especially for crimes of violence, were in slow decline in the late 19th century; increases in the 20th century were quite modest until after the second World War. The crime curve is, frankly, mysterious; it fits none of the obvious theories of crime. It would be hard to correlate the data with economic conditions, or with levels of severity of punishment, for example. Here, then, is a case in which the data raise a question, but do not answer it. Still, this, too, can be seen as an advance. New secrets and mysteries, and buried tombs, are better than wrong-headed certitudes, which are all too common in this field. 